第 56 回日本良導絡自律神経学会学術大会〈シンポジウム発表〉

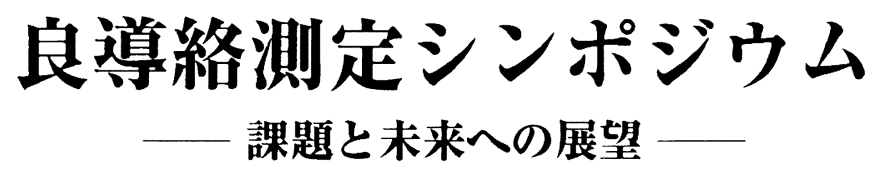

\title{
A problem and the prospect to the future
}

\section{後藤 公哉}

\section{[Summery]}

Several specific neurometry patterns on Ryodoraku chart were reported. Last year, I director of department of sciences of J.S.R.M, call to all members of the society to send me the date of neurometry on lumbago and sciatic to analysis.

This time, I would like to report the result of the accumulation and extend the discussion as the usefulness and necessity of Ryodoraku chart for future.

Each item myofasical lumbago, articular lumbago and sciatic were accumulated this time. In the cases myofasical lumbago was much in male as in female, and much of articular Lumbago and sciatic were appeared in females as in males.

Average age of myofasical lumbago was 35 years old and of sciatic was 55 years old.

By each disease $\mathrm{F} 2 \cdot \mathrm{H} 5$ excitement, $\mathrm{F} 3$ inhibition appeared, and in sciatic F-group restrain was obvious.

The pain a patient of the present age hold, such as by F2 excitement asthenopia, by hypoepinephry by F3 restraint, by F5 restraint asthenopia, migraine parttcipate in stress, therefore, it seems to be necessitate of therapeutic approach on both of mental and somatic.

Simplicity and easiness of the measurement seems to need from a flow of the times,

But it seems important to achieve better communication between patients too, through to spend the time doing the conventional measurement.

In today' s needs, Nakatani' s original Ryodoraku chart has enough usefulness for grasping patient' s condition and explanation of treatment policy to patient.

【はじめに】

良導絡のノイロメトリーは過去にいくつか のパターンが報告されている。学術部では、 腰痛・坐骨神経痛におけるノイロメトリー集 積を全国へ呼びかけ、集積を行った。

集積の結果報告と良導絡チャートの今後の 利用法について考えてみた。
【集 積】

各支部と全国の学術部員に 10000 例を目標 に集積を依頼した。提出は 873 例であった。 (図 1)

類似した健康測定器 (COAMO一ARDK) で1)、ロシア・ドイッ・台湾の科学者たちに より 35 年間研究され 300 万例を超える臨床 データを蓄積し解析データにより健康に関す

1）後藤鍼炎整体療院

于 221-0076 横浜市神奈川区白幡町2-8 Tel. 045-401-3917 Fax. 045-401-7389

E-mail: go0101@mx4.mesh.ne.jp HP http://www.ryodoraku-goto.com

キーワード：腰痛・坐骨神経痛集栍・企業戦士健康チェック・医心上工 
る病気や予防の的確な情報提供がされている。

人は自身の身体の情報を求めている、健康 状態を短時間で数值化し説明できる良導絡測 定は行なって頂きたいと思う。提出しなかっ
た会員は、測定を行なっていないか、協力で きないかどちらかと思われる、残念なことで ある。ご協力頂いた会員にこの場をかりて御 礼申し上げる次第である。

\begin{tabular}{|c|c|c|c|c|c|c|c|}
\hline & 県名 & 氏 名 & コ忆ール群 & 筋膜性 & 関節性 & 坐骨痛 & 計 \\
\hline 1 & 神奈川 & & \begin{tabular}{|l|}
30 \\
\end{tabular} & 30 & 30 & 30 & 120 \\
\hline 2 & 東京 & & 30 & 30 & 30 & 30 & 120 \\
\hline 3 & 北海道 & & 30 & 14 & 3 & 25 & 72 \\
\hline 4 & 東京 & & 30 & 30 & 11 & 27 & 98 \\
\hline 5 & 三重 & & 15 & 3 & 0 & 7 & 25 \\
\hline 6 & 東京 & & 30 & 30 & 30 & 30 & 120 \\
\hline 7 & 神奈川 & & 0 & 11 & 6 & 2 & 19 \\
\hline 8 & 千葉 & & 28 & 22 & 16 & 12 & 78 \\
\hline 9 & 千葉 & & 0 & 4 & 9 & 7 & 20 \\
\hline 10 & 大阪 & & 56 & 24 & 0 & 1 & 81 \\
\hline 11 & 大阪 & & 30 & 22 & 13 & 9 & 74 \\
\hline 12 & 大阪 & & 11 & 17 & 13 & 5 & 46 \\
\hline & 合計 & & 290 & 237 & 161 & 185 & 873 \\
\hline
\end{tabular}

図 1 集積提出者（提出順・敬称略）

【中谷医院 1000 例の良導絡興抑比率】

中谷医院 1000 例のノイロメトリーでは、 H3H4H5 興奮 F3F5 抑制が著明であった。(困 2)

この型は中谷医院独特の型であって、他の 治療院においても同じ型が現れるとは限らな
い。なぜなら神経痛・胃下垂・喘息・ノイロー ゼの患者が多く、他治療院で同じような比率 で現れるとは考えられない。各病名毎に統計 をとり、大阪医大麻酔科のムチウチ症パター ン等のような一定の型が現れるならば意義が あると述べられている2。

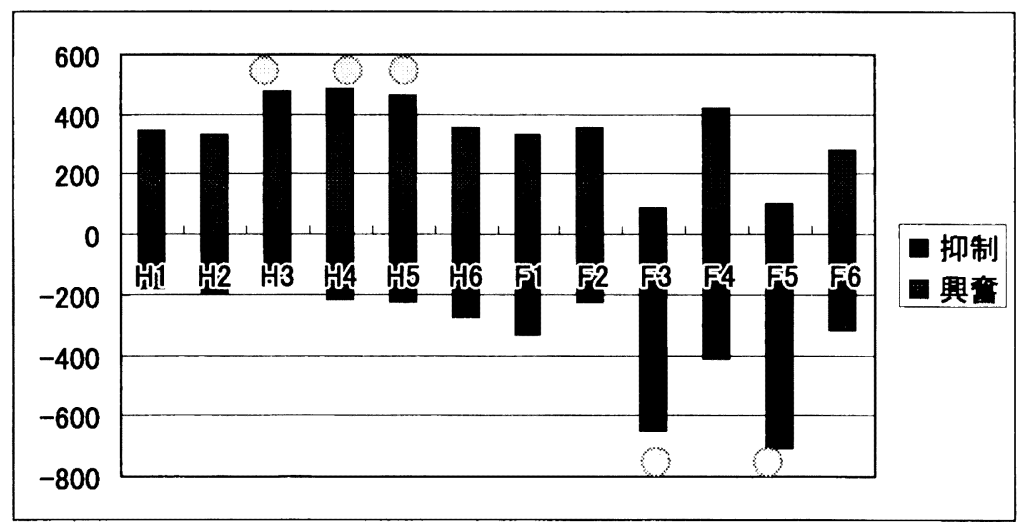

図2 中谷医院 1000 例良導絡興抑比率（1968 年）

\section{【Control 群】(図 3)}

集積した各治療院のノイロメトリーであ る。似たような興抑であるが、筆者と中島で はH5興F3 抑、竹之内、吉備、今井では、F2
興 F5 抑、吉田では、H6興 F5 抑、中根では、 F2 興 F4 抑、㕕田では、H5 興 F5 抑、佐川で は、F6興F1抑、森川では、H5興F4抑と少し ずつ違いがある。 

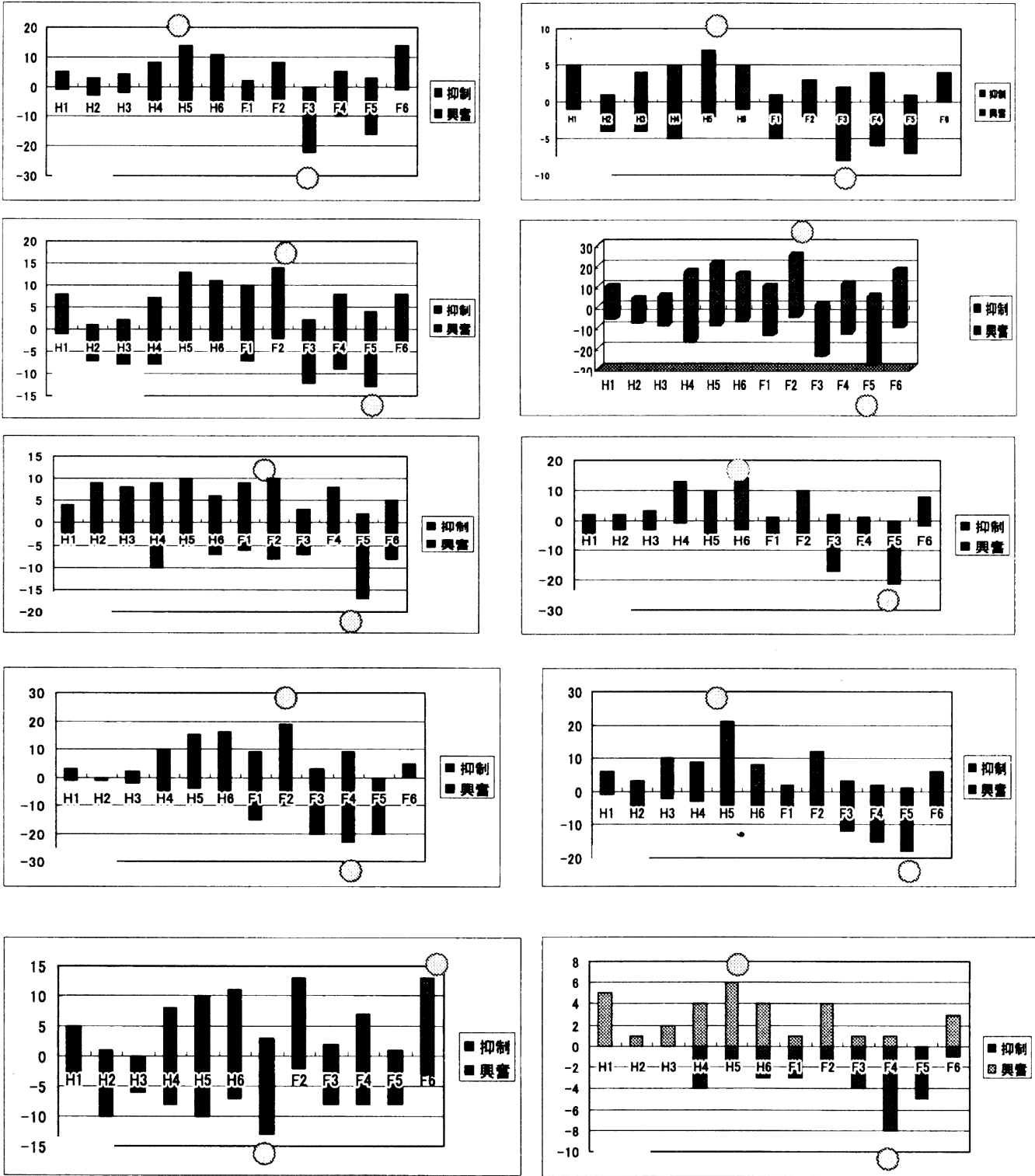

図3

【腰痛以外 Control 群】（図 4)

H5F2興奮、F3F5 抑制が著明で最も興抑各

肩こり·頭痛等でControl群として主訴に腰

1 ツずつでも同様であった。

痛・坐骨神経痛のないものを集積した。
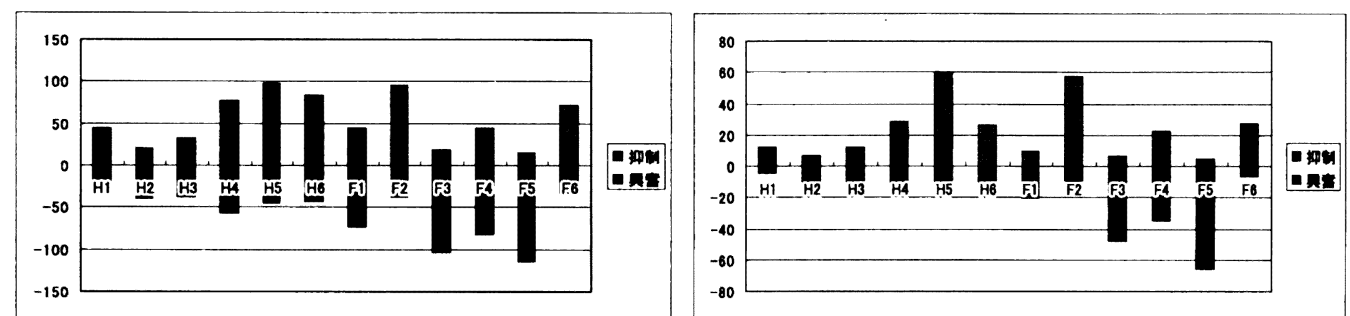

図 4 


\section{【筋筋膜性腰痛】（図 5)}

腰痛には、箭筋膜性の他各種の腰痛がある が、ここでは、笳筋膜性腰痛、筋筋膜性以外 の腰痛と坐骨神経痛に有意差があるかどうか
を集積した。

H5F2興奮、F3F5 抑制が著明で、最も興抑 各 1 ツずつではF2の興が著明であった。
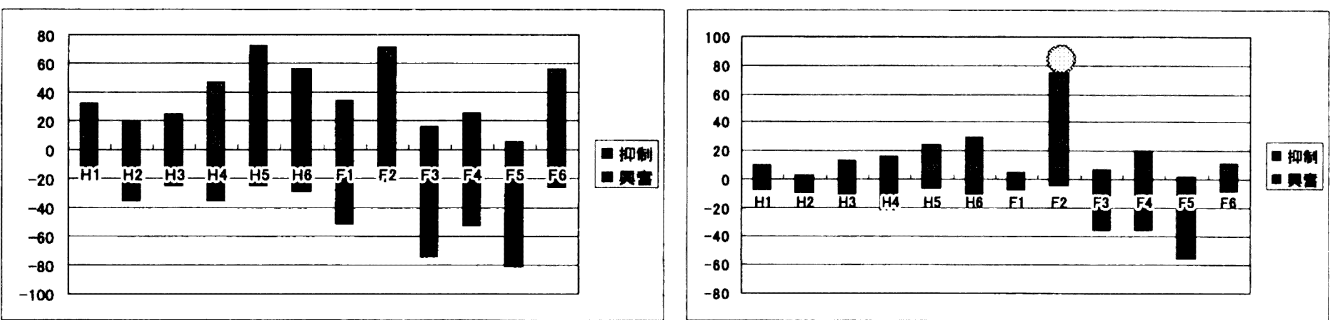

図 5

\section{【筋筋膜性以外の腰痛】}

H5F2F6興奮、F3F4F5抑制が著明であった。
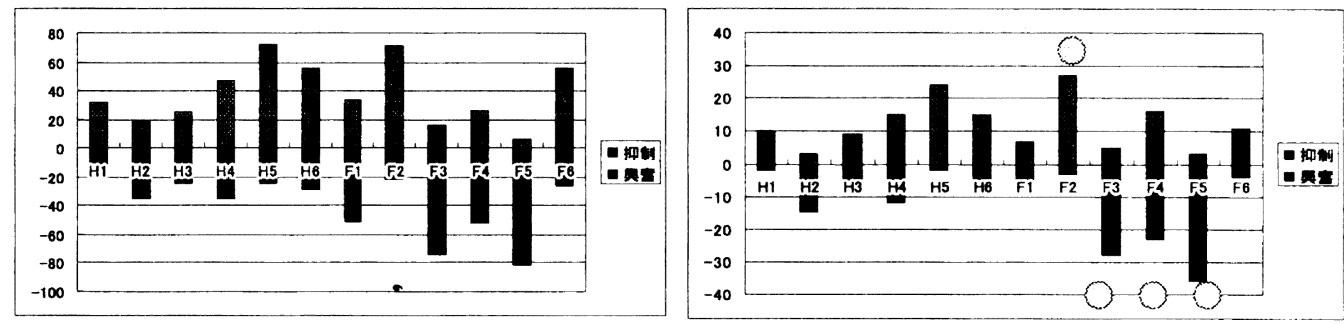

図 6

【坐骨神経痛】 F 系の抑制が著明でした。
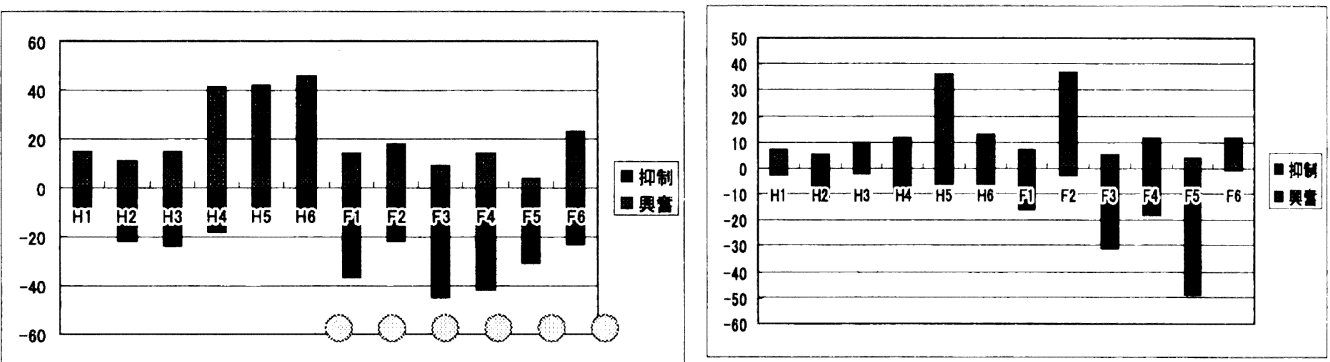

図 7

\section{【結 果】}

今回、筋筋膜性腰痛、筋筋膜性以外の腰痛 と坐骨神経痛の集積を行った。873例中、筋筋 膜性では男性が多く、筋筋膜性以外の腰痛・ 坐骨神経痛では女性が多かった。平均年龄は 筋筋膜性で35才、坐骨神経痛では55才であっ た。筋筋膜性腰痛ではF2の興奮、筋筋膜性以 外の腰痛ではF2の興畕にF3F4F5の抑制が出 現し、各疾患で H5の興奮、F3の抑制、坐骨
神経痛では F 系の抑制が著明であった。筆 者の 1998 年の統計と同様のパターンが出 現した ${ }^{3)}$ 。

Control群ではH4H5H6の興禽 F3F5の抑制 があらわれ、中谷医院 1000 例のノイロメト リーと類似した。今回の各治療院集積におい てF2の興奮が著明であった。これは現代社会 におけるストレスが影響していると考えられ る。 


\begin{tabular}{|c|c|c|c|c|}
\hline & 定㖪 & 平约值类奮 挪制 & 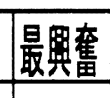 & \\
\hline & \begin{tabular}{ll|l|l|l|l|l|}
290 & 113 & 171 & 41 \\
\end{tabular} & \begin{tabular}{ll|l}
36.4 & 45522 & $F 5 F 3$ \\
\end{tabular} & fF & \\
\hline & \begin{tabular}{ll|l|l|l|l|l|l|}
2326 & 111 & 35 \\
\end{tabular} & \begin{tabular}{ll|l}
40.6 & $\mathrm{HH} 5 \mathrm{~F}$ & $\mathrm{F5F3}$ \\
\end{tabular} & & \\
\hline & \begin{tabular}{ll|l}
56 & 101 & 43 \\
\end{tabular} & \begin{tabular}{|l|l|l|l|}
$45 H 6$ & $F 3 F 5$ \\
\end{tabular} & 12 & \\
\hline & \begin{tabular}{|l|l|l|l|l|l|}
583 & 102 & 55 \\
\end{tabular} & 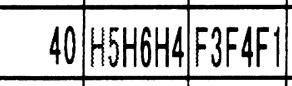 & II55-2 & \\
\hline & \begin{tabular}{l|l|l|l|}
873 & 378 & 491 & 44
\end{tabular} & \begin{tabular}{|l|l|}
$H 5$ & $F 3$ \\
\end{tabular} & & \\
\hline
\end{tabular}

図 8

\section{【考 察】}

\section{H5（リンパ）の興奮}

リンパと副交感神経に関係し、自覚症状が 少ないと症候群表では示されている3)。リン パ液は運動による筋活動により循環する。痛 みにより動かないことで、古いリンパ液の循 環が停滞し免疫系の活性化に影響を与えてい ると思われる。

\section{F3 (腎) の抑制}

副腎機能、抵抗力、自然治癒力の低下を現 し、F3 (腎) は腰と関係し足の内側より腹部 を走行することから、腹筋の弱体を表現して いるものと考えられる。

\section{F2（肝）の興韵}

筋肉痛と不眠、気分不快と症候群表では説 明されている3)。筋肉性腰痛の他に精神的ス

トレスも含まれているものと思われる。

control群を含め全てにF2 (肝) の興奮が著 明であった。

中谷が集積したデータと今回のデータでは 患者の病態に違いがあるように思われる。F2 興の眼精疲労やF3抑の副腎機能低下 (ストレ ス)、F5の目の疲れや偏頭痛など、現代の患 者の抱えるストレスなどが痛みに関係し心と 身体、精神的治療のアプローチが必要と思わ れる。

\section{F5 (胆) の抑制}

胆が衰えると不安感が強く、ため息が多 く、いらいら、びくびくして驚きやすくなり、 精神的なストレスに対する抵抗力が弱まり、 不眠が続き、ストレス障害を引き起こず)。こ
こでは、痛みからくるストレスがF5（胆）の 抑制を現しているものと思われる。

\section{【末来への展望】}

良導絡測定は交感神経の興奮性を数値で客 観的に捉えられることが特徴の一つである。

手首、足首の代表測定点を同時に測定する 方法なども提案されている。

ここでは、従来の測定結果の組み合わせに よる健康チェックを考えてみた。

\section{【良導絡チャートによる企業戦士の健康}

チェック】

仮名を企業戦士健康チェックとし平均值よ り、

$100 \mu \mathrm{A}$ 以上を 5 点 $\cdot 80 \sim 90 \mu \mathrm{A}$ を 3 点. $70 \sim 80 \mu \mathrm{A}$ を 2 点. $60 \sim 40 \mu \mathrm{A}$ を 0 点

$40 \sim 30 \mu \mathrm{A}$ を 2 点· $30 \sim 20 \mu \mathrm{A}$ を 3 点. $10 \mu \mathrm{A}$ 以下を 5 点とし、左右差の数、2 3ケ を 1 点 4 〜 ケを 2 点 7 ケ以上を 3 点とした。

\begin{tabular}{|l|c|}
\hline 平均值 $\mu \mathrm{A}$ & 点 数 \\
\hline 100 以上 & 5 点 \\
\hline $80 \sim 90$ & 3 点 \\
\hline $70 \sim 80$ & 2 点 \\
\hline $60 \sim 40$ & 0 点 \\
\hline $40 \sim 30$ & 2 点 \\
\hline $30 \sim 20$ & 3 点 \\
\hline 10 以下 & 5 点 \\
\hline
\end{tabular}

図 9 平均値よりのチェック 


\begin{tabular}{|l|c|}
\hline \multicolumn{1}{|c|}{ 数 } & 点 数 \\
\hline $2 \sim 3$ & 1 点 \\
\hline $4 \sim 6$ & 2 点 \\
\hline 7 以上 & 3 点 \\
\hline
\end{tabular}

図 10 左右差よりのチェック
他に H5F3 興奮精神症状大（Dr. 飯田）

F3F5 抑制 W パターン痛みの慢性（Dr。早 崎）等各 1 点を追加する。

\begin{tabular}{|c|c|}
\hline HF 分離 (F 系が $\mathrm{H}$ 系より高い場合) & 4 点 サンドイッチ症候群 \\
\hline F2 興奮 & 1 点 戦闘過剩症候群 \\
\hline F2H3 興奮 & 2 点 上昇停止症候群 \\
\hline F2F3 興奮 & 3 点 出社拒否症候群 \\
\hline F5F6 興奮 & 2 点 燃えつき症候群 \\
\hline H4H5H6 抑制 & 3 点 五月病症候群 \\
\hline F1F2F3F4 興奮 F5F6 抑制 & 4 点 心身症 \\
\hline 興抑錯乱 & 5 点 $\quad$ SOS \\
\hline
\end{tabular}

図 11 【興塞抑制よりのチェック】

\section{【評価表】}

\begin{tabular}{|l|l|}
\hline スコワー & $0 \sim 10$ 点 \\
\hline 0 点 & 正常 きわめて健康 \\
\hline $1 \sim 3$ 点 & 健康 \\
\hline $4 \sim 6$ 点 & 疲労予備群 \\
\hline $6 \sim 9$ 点 & 完全疲労治療必要 \\
\hline 10 点以上 & きわめて危険積極的治療が必要 \\
\hline
\end{tabular}

図12 良導教チャートによる企業戦士の保康チェック䛨西表

\section{【症例】 $邓$ 銀行役員 55 歳主訴腰痛}

平均值 $80 \mu \mathrm{AH}$ 系 $93 \mu \mathrm{AF}$ 系 $67 \mu \mathrm{A}$

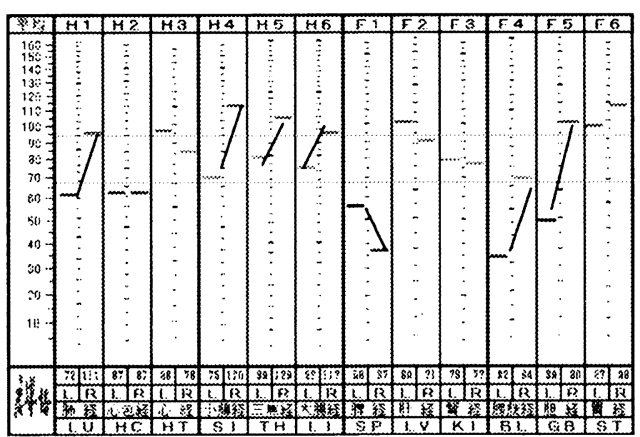

図 13

平均值 $80 \mu \mathrm{A}$ : (3 点) 左右差 $7:$ (3 点) F2H3 興奮 : (3点) F5F6 興奮 : (2点) 合計：11点 出社拒否 燃えつき症候群 積極的治療が必要である。

\section{【おわりに】}

時代の流れから測定の簡便化も必要と思わ れるが、従来の測定法により、時間をかける ことによる患者とのコミニケーションも大切 である。

良導絡チャートは、現在のままでも充分に 病態把握と患者への病気や治療方針の説明に 有効である。時代のニーズに応じた展開が期 待される。

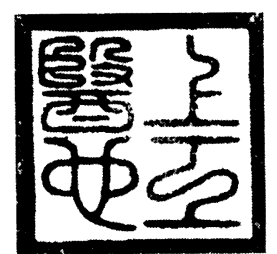

中医の印に医心上工と いうのがある。未病を実 践できる卓越した医師を 上工、疾患だけしか治す ことを知らない医師を下 工とランク付けがされている ${ }^{5)}$ 。良導絡測定 を行なって上工を志さなければと考えている。

\section{【参考文献】}

1) COSMO-ARDK

(有) プログレスインターナショナル事業部

2 ) 中谷義雄 良導絡自律神経調整療法 p127 東京良導絡研究所 1987

3 ）後藤公哉 良導絡療法基礎と臨床 p17-18 p279エンタプライズ(株) 1999

4 ) 内山恵子 中医診断学ノート p124 東洋学術出版社 1989

5 ) 丹澤章八 鍼炎と未病一漢方のアプローチと 対応戦略一漢方と最新治療 13 巻 2 号 2004 